\title{
Phytochemical characterization and antioxidant potential of rustyback fern (Asplenium ceterach L.)
}

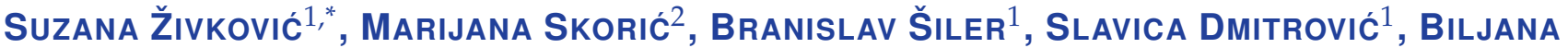

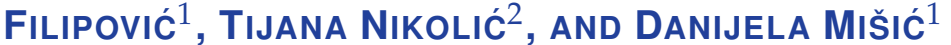 \\ ${ }^{1}$ Institute for Biological Research "Siniša Stanković, University of Belgrade, Bulevar despota Stefana 142, 11060 Belgrade, Serbia \\ ${ }^{2}$ Faculty of Biology, University of Belgrade, Takovska 43, 11060 Belgrade, Serbia \\ *Corresponding author: suzy@ibiss.bg.ac.rs
}

Received: October 12, 2017

Accepted: October 15, 2017

Published on-line: October 16, 2017

Published: December 25, 2017

\begin{abstract}
Asplenium ceterach L. (syn. Ceterach officinarum Willd.) or rustyback fern is a plant species traditionally used in Mediterranean countries as an expectorant, diuretic, against spleen complaints, kidney stones and hemorrhoids. Phytochemical analysis of gametophytes and sporophytes of A. ceterach was performed, followed by comparative analysis of phenolic composition and the antioxidant properties of the extracts (scavenging capacities against ABTS $\bullet^{+}$and DPPH $\bullet$ ). Totally 16 phenolic compounds belonging to the classes of phenolic acids (hydroxybenzoic and hydroxycynnamic acids), flavonoids (flavan-3-ols, flavonols), and xanthones were identified using UHPLC/DAD/-HESI-MS/MS analysis. Different phenolics' composition of the two phases of the life cycle of this fern was observed which significantly determined their radical scavenging activities. In sporophytes of $A$. ceterach considerably high amounts of chlorogenic acid were found $\left(\sim 21 \mu \mathrm{g} 100 \mathrm{mg}^{-1}\right.$ fresh weight), while xanthones were the most abundant in gametophytes (mangiferin glucoside, reaching $2.54 \mu \mathrm{g} 100 \mathrm{mg}^{-1}$ fresh weight), recommending this fern species as a valuable source of bioactive compounds.
\end{abstract}

Key words: Asplenium ceterach, fern, sporophyte, gametophyte, antioxidant activity, phenolics

\section{INTRODUCTION}

Ferns (Class Polypodiopsida) include over 12,000 species, many of which being of ornamental, medicinal, and ethnobotanical importance, or with a specific role in habitat conservation (Soare, 2008). Very few works have been done on the phytochemical composition of ferns, even though their ethnobotanical importance has been investigated and studied by numerous authors (De Britto et al., 2012). Ferns are peculiar in having the life cycle which alternates between two distinct phases: a diploid sporophyte and a haploid gametophyte, the former representing the asexual, spore-producing phase and the later the sexual, gamete-producing generation. This feature provides an opportunity for monitoring bioactivity and changes in the content of bioactive compounds in both sporophytic and gametophytic plant bodies Pauline Vincent et al. (2012). However, phytochemical investigations of fern gametophytes are rarely performed, since they are characterized by fragile structure, microscopic dimensions, and difficult collection procedure. Asplenium ceterach L. (syn. Ceterach officinarum Willd., family Aspleniaceae) or rustyback is widely spread fern species in Europe, North Africa, and the Near East. It is being used medicinally as a diuretic, expectorant, against spleen complaints, kidney stones and hemorrhoids (Vokou et al., 1993; Guarrera and Lucia, 2007). Its aqueous extracts were reported to show antioxidant, antimicrobial and DNA damage protection potentials (Berk et al., 2011). Bioactive components of ferns mainly belong to the phenolic, flavonoid, alkaloid, and terpenoid families Ho et al. (2011), and Asplenium species, mainly sporophytes, have been only partially phytochemically characterized (Durdevic et al., 2007; Mir et al., 2013).

To the best of our knowledge, this study is the first report of comparative phytochemical analysis of gametophytes and sporophytes of Asplenium ceterach, aiming to further explore the relationship between their phenolic profiles and antioxidant activity.

\section{MATERIALS AND METHODS}

\section{Plant material}

Mature sporophytes of rustyback (Asplenium ceterach L.) were collected during September 2013 in Krepoljin (Eastern Serbia) and further grown in a greenhouse of the Institute for Biological Research "Siniša Stanković", Belgrade (Serbia), at the temperature of $25 \pm 2^{\circ} \mathrm{C}$ and a relative humidity of $60-90 \%$. Spores for in vitro gametophyte establishment were taken 
from single sporophytes and kept at $-20^{\circ} \mathrm{C}$ until use. Sterilized spores were germinated on half-strength MS medium (Murashige and Skoog, 1962) with $20 \mathrm{~g} \mathrm{~L}^{-1}$ sucrose, $7 \mathrm{~g} \mathrm{~L}^{-1}$ agar (Torlak, Serbia) and $0.1 \mathrm{~g} \mathrm{~L}^{-1}$ myo-inositol (Merck, Germany). Gametophyte cultures were grown aseptically in $9 \mathrm{~cm}$ Petri-dishes under white fluorescent tubes $(8 \mathrm{~h}$ light $/ 16 \mathrm{~h}$ dark cycle) with a photon flux density of $50 \mathrm{mmol}^{-2} \mathrm{~s}^{-1}$, at $25 \pm 2{ }^{\circ} \mathrm{C}$ and a relative humidity of $60-70 \%$.

\section{Plant methanol extracts preparation}

Plant material was powdered in mortars using liquid nitrogen and extracted with $80 \%$ methanol (AppliChem, USA). After centrifugation for $10 \mathrm{~min}$ at $10000 \times g$, the supernatants were collected and filtered (pore size $0.45 \mu \mathrm{m}$, Econofilter, Agilent Technologies, USA) prior to analyses or further assays. All extractions were performed in triplicate.

\subsection{Determination of total phenolic content}

Total phenolic concentration (TPC) was quantified using FolinCiocalteau assay (Singleton and Rossi, 1965) with minor modifications (Šiler et al., 2014). The TPC was calculated from a standard calibration curve based on gallic acid and results were expressed as mg of gallic acid equivalents (GAE) per $g$ of fresh weight (mg GAE g $\left.{ }^{-1} \mathrm{FW}\right)$.

\subsection{UHPLC/DAD/QQQ MS conditions for targeted metabolomics analysis}

Separation, identification, and quantification of components in methanol extracts of gametophytes and sporophytes was performed using Dionex Ultimate 3000 UHPLC system (Thermo Fisher Scientific, Germany) equipped with a diode array detector (DAD) and connected to a triple-quadrupole mass spectrometer. Elution was performed at $40^{\circ} \mathrm{C}$ on Syncronis $\mathrm{C} 18$ column $(100 \times 2.1 \mathrm{~mm})$ with $1.7 \mu \mathrm{m}$ particle size (Thermo Fisher Scientific, USA). The mobile phase consisted of (A) water $+0.1 \%$ formic acid, and (B) acetonitrile (MS grade, Fisher Scientific, UK), which were applied in the following gradient elution: $5 \% \mathrm{~B}$ in the first $2.0 \mathrm{~min}, 2.0-12.0 \mathrm{~min} 5-95 \% \mathrm{~B}$, $12.0-12.2 \mathrm{~min}$ from $95 \%$ to $5 \% \mathrm{~B}$, and $5 \% \mathrm{~B}$ until the $15^{\text {th }} \mathrm{min}$. The flow rate was set to $0.4 \mathrm{~mL} \mathrm{~min}^{-1}$ and the detection wavelengths to 260 and $320 \mathrm{~nm}$. The injection volume was $5 \mu \mathrm{L}$. All analyses were performed in triplicate.

A TSQ Quantum Access Max triple-quadrupole mass spectrometer (Thermo Fisher Scientific, Switzerland) equipped with a heated electrospray ionization (HESI) source was used. The vaporizer temperature was set to $200^{\circ} \mathrm{C}$, while ion source settings were as follows: spray voltage $5000 \mathrm{~V}$, sheet gas $\left(\mathrm{N}_{2}\right)$ pressure $40 \mathrm{AU}$, ion sweep gas pressure $1 \mathrm{AU}$ and auxiliary gas $\left(\mathrm{N}_{2}\right)$ pressure $8 \mathrm{AU}$, capillary temperature $300^{\circ} \mathrm{C}$, skimmer offset $0 \mathrm{~V}$. Collision-induced fragmentation experiments were performed using argon as the collision gas, and the collision energy $(\mathrm{cE})$ varied depending on a compound. Time selected reaction monitoring (tSRM) experiment for quantitative analysis of 16 phenolic compounds was performed by using two MS2 fragments for each compound. Xcalibur software (version 2.2) was used for the instrument control, data acquisition, and analysis.

Phenolics were identified by the direct comparison with the commercial standards (Sigma Aldrich, Germany) and by the comparison with the literature data. The total amount of each targeted compound in sporophyte (S) or gametophyte $(\mathrm{G})$ samples was calculated based on the calibration curve of pure compound and expressed as $\mu \mathrm{g} 100 \mathrm{mg}^{-1}$ FW. Mangiferin glucoside was quantified using calibration curve of mangiferin.

\section{3. $D P P H$ and $A B T S$ radical scavenging activity}

DPPH assay was performed as previously described by BrandWilliams et al. (1995), with slight modifications (Šiler et al., 2014). The 2,2'-azino-bis-3-ethylbenzthiazoline-6-sulphonic acid (ABTS) radical cation decolorization assay was determined spectrophotometrically using the method of Re et al. (1999), modified for this assay. All the analyses were run in triplicate and mean values were calculated. The percentage of scavenging activity was plotted against the sample concentration to obtain the $\mathrm{IC}_{50}$, defined as the concentration of sample necessary to cause $50 \%$ inhibition.

\subsection{Statistical analysis}

Statistical analyses were performed using STATGRAPHICS software, v. 4.2 (STSC Inc. and Statistical Graphics Corporation, USA). The quantification data were subjected to Student's $\mathrm{t}$-test to compare the mean values of samples (sporophytes and gametophytes). The data obtained in antioxidant assays were subjected to the analysis of variance (ANOVA), and the comparisons between the mean values of treatments were made by the least significant difference (LSD) test calculated at the confidence level of $\mathrm{P}<0.05$.

\section{RESULTS AND DISCUSSION}

A total of 16 phenolic compounds were identified in samples of $A$. ceterach belonging to phenolic acids (hydroxybenzoic and hydroxycinnamic acids), flavonoids (flavan-3-ols and flavonols), and xanthones. The analysis included a comparison of the retention times, UV and MS spectra with the available standards in UHPLC/DAD/-HESI-MS/MS analysis. The UHPLC/-HESI-MS/MS data and the major -MS ${ }^{2}$ product ions of the compounds detected, as well as DAD data $\left(\lambda_{\max }\right)$, are presented in Table 1. Corresponding UHPLC-MS/MS and UHPLC-DAD chromatograms are shown in Figure ??.

The following hydroxybenzoic acids were identified in the samples: protocatechuic acid and gentisic acid both showing $m / z[\mathrm{M}-\mathrm{H}]^{-}$of 153 , and $p$-hydroxybenzoic acid with $m / z[\mathrm{M}-\mathrm{H}]^{-}$ at 137. Protocatechuic acid was the most abundant compound, especially in sporophytes $\left(\sim 0.47 \mu \mathrm{g} 100 \mathrm{mg}^{-1} \mathrm{FW}\right)$. Aesculin, chlorogenic, caffeic, $p$-coumaric, and rosmarinic acids belonging to the hydroxycinnamic acids and showing molecular ions $m / z[\mathrm{M}-\mathrm{H}]^{-}$at $339,353,179,163$, and 359 , respectively, were also identified. Hydroxycinnamic acids were shown to be the dominant phenolic compounds in sporophytes of $A$. ceterach, with chlorogenic acid being by far the most abundant (Table 1), reaching concentration of $\tilde{2} 1 \mu \mathrm{g} 100 \mathrm{mg}^{-1} \mathrm{FW}$. Among the phenolic acids, $p$-coumaric, caffeic, ferulic, $p$-hydroxybenzoic, and chlorogenic acids have been previously reported for $A$. unilaterale (Bohm, 1968; Glass and Bohm, 1969), while catechol derivatives have been identified in A. adiantum-nigrum (Bohm, 1968). To the best of our knowledge, there are no literature data on phenolic acids' content for A. ceterach. Flavonoids identified in sporophytes and gametophytes of rustyback belong to either flavan-3-ols (gallocatechin, epigallocatechin, catechin, epicatechin, and epigallocatechin gallate) or flavonols (rutin) (Table 1). Flavan-3-ols were more abundant in A. ceterach gametophytes than in sporophytes, where gallocatechin $(\tilde{0} .52$ $\left.\mu \mathrm{g} 100 \mathrm{mg}^{-1} \mathrm{FW}\right)$ and epigallocatechin gallate $(\tilde{0} .41 \mu \mathrm{g} 100$ $\mathrm{mg}^{-1} \mathrm{FW}$ ) were the major compounds from this group. Interestingly, sporophytes preferably accumulated epicatechin $\left(\sim 0.12 \mu \mathrm{g} 100 \mathrm{mg}^{-1} \mathrm{FW}\right)$, while catechin $\left(\sim 0.15 \mu \mathrm{g} 100 \mathrm{mg}^{-1} \mathrm{FW}\right)$ was present only in gametophytes. Both compounds showed molecular ions $m / z[\mathrm{M}-\mathrm{H}]^{-}$at 289 . Flavan-3-ols have not been previously reported for $A$. ceterach, and are only rarely identified in species from this genus (Ondo et al., 2013). Interestingly, rutin $\left(m / z[\mathrm{M}-\mathrm{H}]^{-}\right.$at 609$)$ was the only flavonol identified in $A$. ceterach, and has been previously reported for ferns belonging to other genera (Ansari and Ekhlasi Kazaj, 2012). Rutin $\left(\sim 0.06 \mu \mathrm{g} 100 \mathrm{mg}^{-1} \mathrm{FW}\right)$ was present only in gametophytes of A. ceterach. Further analysis of phenolics in sporophytes and gametophytes of $A$. ceterach revealed the presence of xanthones: mangiferin glucoside with molecular ion $m / z[\mathrm{M}-\mathrm{H}]^{-}$of 


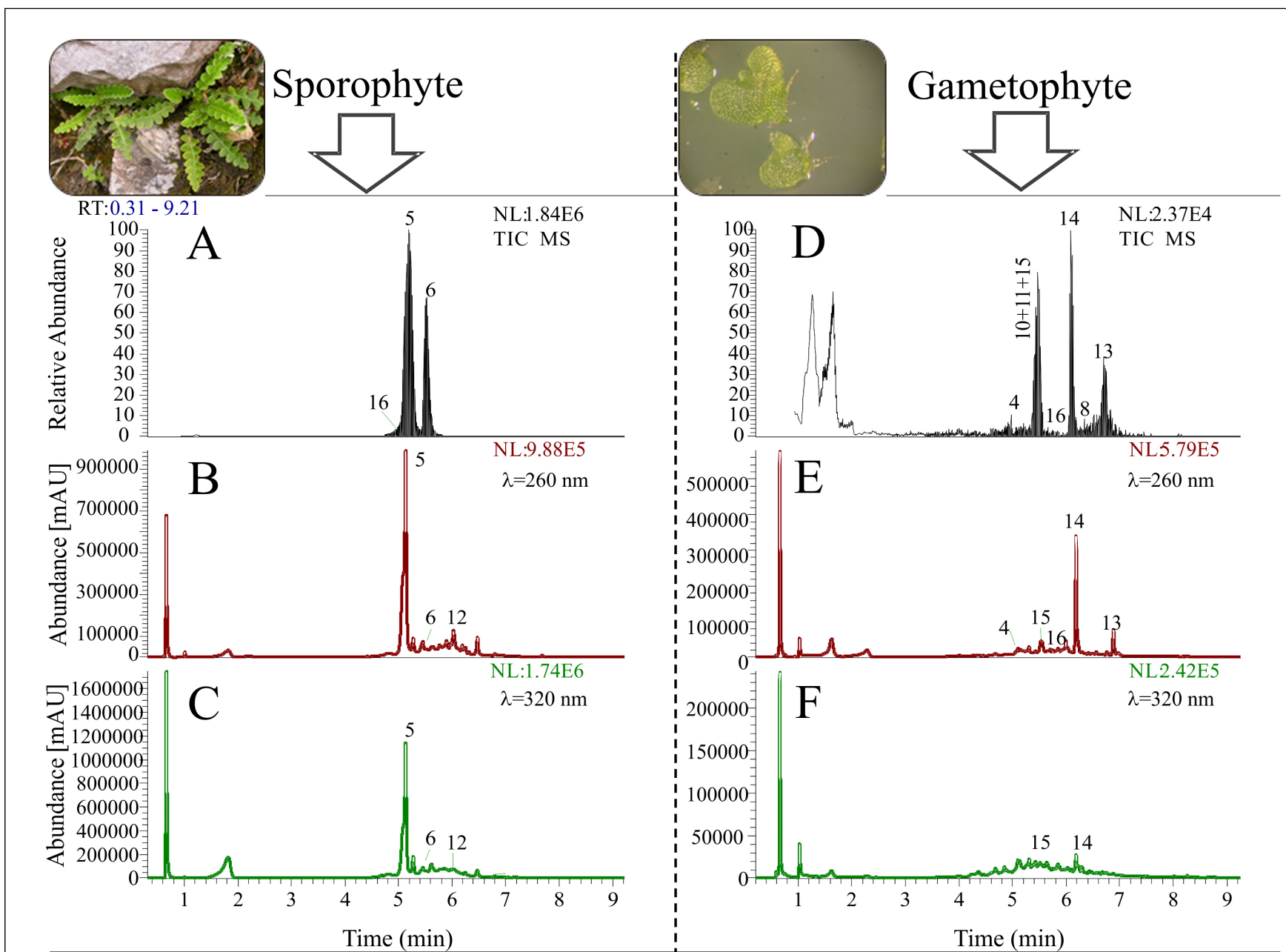

Fig. 1. Methanol extracts of Asplenium ceterach gametophytes and sporophytes-fronds were analyzed using UHPLC/DAD/-HESI-MS/MS method, and first $9 \mathrm{~min}$ of the analysis is presented. UHPLC/-HESI-MS/MS Total Ion Chromatogram (TIC) of sporophyte (A) and gametophyte (D) show major peaks corresponding to: (4) aesculin; (5) chlorogenic acid; (6) caffeic acid; (8) rosmarinic acid; (10) epigallocatechin; (11) catechin; (13) epigallocatechin gallate; (14) rutin; (15) mangiferin glucoside; (16) mangiferin. Peak numbers correspond to the compounds listed in Table 1. Chromatograms of sporophytes (B and C) and gametophytes (E and F) represent UHPLC-DAD chromatograms at $\lambda=260 \mathrm{~nm}$ and $\lambda=320 \mathrm{~nm}$, respectively.

583 and mangiferin showing $m / z[\mathrm{M}-\mathrm{H}]^{-}$of 421 . Gametophytes of A. ceterach were especially rich in mangiferin glucoside,

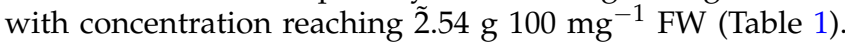
Mangiferin was present in significantly lower amounts $(\sim 0.01$ $\left.\mu \mathrm{g} 100 \mathrm{mg}^{-1} \mathrm{FW}\right)$. The presence of xanthones was previously reported in sporophytes of $A$. ceterach (Imperato, 1983). To the best of our knowledge, this is the first record of mangiferin and mangiferin glucoside in gametophytes of ferns in general. In the recent years, much attention has been devoted to ferns as potential sources of natural antioxidants, and several Asplenium species have been evaluated for their antioxidant potential (Lai et al., 2009; Talukdar et al., 2011; Ondo et al., 2013; Andrade et al., 2014). High superoxide anion and nitric oxide radical scavenging activities have been determined for A. ceterach, as well as significant radical scavenging activity against DPPH radical (Berk et al., 2011; Karadeniz et al., 2015). Methanol extracts of sporophytes and gametophytes of A. ceterach exhibited scavenging capacities against both ABTS and DPPH radicals. Regarding radical scavenging activity, more efficient were the fronds of $A$. ceterach sporophyte (Table 2 ), showing $\mathrm{IC}_{50}$ values of 0.46 and $0.18 \mathrm{mg} \mathrm{mL}-1$ for $\mathrm{DPPH}$ and ABTS assays, respectively. Antioxidant activity can be ascribed to high phenolics' content ( 232 $\left.\mathrm{mg} \mathrm{GAE} \mathrm{g}^{-1} \mathrm{FW}\right)$, especially to chlorogenic acid, the major compound found in the methanol extracts in sporophytes. Chlorogenic acid is well-known for its high antioxidant potential (Xu et al., 2012;
Kamiyama et al., 2015). Gametophytes displayed lower TPC ( 51 $\left.\mathrm{mg} \mathrm{GAE} \mathrm{g}^{-1} \mathrm{FW}\right)$ and thus lower antioxidant activity in DPPH and ABTS assays than sporophytes. areXanthone mangiferin glucoside is most likely mainly responsible for the antioxidant activity of $A$. ceterach gametophytes and is followed by the flavan-3-ols. Mangiferin has previously been reported to show very good antioxidant potential in both ABTS and DPPH assays (Šiler et al., 2014), as well as galloylated and non- galloylated catechins (Rice-Evans et al., 1996; Guo et al., 1999). Methanol extracts of sporophytes displayed higher antioxidant potential than pure compounds (chlorogenic acid, mangiferin and ascorbic acid) used as the reference (Table 2). Among reference compounds, catechin was the most efficient antioxidant in both assays, followed by ascorbic acid and mangiferin. 
Table 1. Phenolics identified in methanol extracts of Asplenium ceterachsporophytes (S) and gametophytes (G), using UHPLC/DAD/-HESI-MS/MS analysis, with peak numbers, expected ranges of retention times $(t \mathrm{R})$, mass of parent ions in a negative ion mode $[\mathrm{m} / \mathrm{z}]$, and masses of product ions $[\mathrm{m} / \mathrm{z}]$ with specified collision energies (eV) used in $t \mathrm{SRM}$ experiment. UHPLC/DAD data, including $t R$, and $\lambda_{\max }$, are also presented. Concentrations of phenolic compounds in samples are presented as $\mu \mathrm{g} 100 \mathrm{mg}^{-1} \mathrm{FW}$.

\begin{tabular}{|c|c|c|c|c|c|c|c|c|c|}
\hline Peak\# & Assignment & Start & Stop & {$[\mathrm{M}-\mathrm{H}]-$} & (collision energy, eV) & $\mathrm{tR}$ & $\operatorname{lmax}$ & $\mathrm{S}$ & G \\
\hline & & {$[\mathrm{min}]$} & {$[\mathrm{min}]$} & {$[\mathrm{m} / \mathrm{z}]$} & {$[\mathrm{m} / \mathrm{z}]$} & {$[\mathrm{min}]$} & {$[\mathrm{nm}]$} & [mg 100 mg-1 FW ] & \\
\hline
\end{tabular}

Phenolic acids and their derivatives

Hydroxybenzoic acids

1 Protocatechuic acid

2 Gentisic acid

3 p-Hydroxybenzoic acid

Hydroxycinnamic acids

$\begin{array}{ll}4 & \text { Aesculin } \\ 5 & \text { Chlorogenic acid } \\ 6 & \text { Caffeic acid } \\ 7 & \text { p-Coumaric acid } \\ 8 & \text { Rosmarinic acid }\end{array}$

8 Rosmarinic acid

\section{Flavonoids and their derivatives}

Flavan-3-ols

$\begin{aligned} 9 & \text { Gallocatechin } \\ 10 & \text { Epigallocatechin } \\ 11 & \text { Catechin } \\ 12 & \text { Epicatechin } \\ 13 & \text { Epigallocatechin gallate }\end{aligned}$

Flavonols

$$
14 \text { Rutin }
$$

Xanthones

15 Mangiferin glucoside

$\begin{array}{lll}3.48 & 4.48 & 153.01 \\ 4.68 & 5.68 & 153.00 \\ 4.58 & 5.58 & 137.06\end{array}$

$\begin{aligned} 108(23) ; 109(14) & 3.77 \\ 108(5) ; 109(15) & 5.13 \\ 93(19) ; 108(22) & 5.03\end{aligned}$

220,260

210,330

210,320

$\begin{array}{lll}4.39 & 5.39 & 339.08 \\ 4.73 & 5.73 & 353.10 \\ 5.01 & 6.01 & 179.00 \\ 5.65 & 6.65 & 163.03 \\ 6.20 & 7.20 & 359.06\end{array}$

$\begin{array}{rrr}133(44) ; 177(25) & 4.80 & 250,350 \\ 191(25) & 5.20 & 230,330 \\ 134(13) ; 135(16) & 5.53 & 230,330 \\ 93(39) ; 119(16) & 6.04 & 230,280 \\ 133(43) ; 161(21) & 6.70 & 240,330\end{array}$

$\begin{array}{lll}3.37 & 4.37 & 305.12 \\ 4.57 & 5.57 & 305.11 \\ 5.00 & 5.50 & 289.09 \\ 5.50 & 6.00 & 289.08 \\ 6.41 & 7.21 & 457.16\end{array}$

125 (27); 179 (17)

125 (27); 179 (17)

3.80

203 (23); $245(31) \quad 5.70$

$161(25) ; 359(16) \quad 6.85$

$5.54 \quad 6.54 \quad 609.20$

300 (42); 301 (32)

6.04

210,270

210, 270

210,270

230,280

230,280

$\begin{array}{lll}4.50 & 5.50 \quad 583.00\end{array}$

301 (20); 331 (20)

$301(20) ; 331(20)$

$4.95260,320,360$

$5.46260,320,360$

$6.00 \quad 421.30$

a All components except Mangiferin glucoside (15) were confirmed by standard

${ }^{\mathrm{b}}$ Within each parameter (compound) independently, values with the same letter are not significantly different at the $\mathrm{P}<0.05$ level according to the LSD test.

\section{$0.471+0.181 * \quad 0.129 \pm 0.001$ $0.007 \pm 0.004$ ns $\quad 0.013 \pm 0.001$ \\ $0.007 \pm 0.004 * \quad 0.115 \pm 0.001$}

$0.082 \pm 0.012 * \quad 0.032 \pm 0.001$ $20.905 \pm 1.811 * \quad 0.058 \pm 0.001$ $0.022 \pm 0.001 * \quad 0.017 \pm 0.001$ $0.089 \pm 0.005$

$0.009 \pm 0.003 * 0.064+0.001$

$0.114+0.066 * \quad 0.516 \pm 0.193$

$\begin{array}{ll}- & 0.153 \pm 0.001\end{array}$

$0.120 \pm 0.041$

$0.061 \pm 0.036 * 0.414 \pm 0.024$

$0.056 \pm 0.006$

$0.011 \pm 0.002 * \quad 2.541 \pm 0.284$ $0.020 \pm 0.001 * \quad 0.011 \pm 0.005$ 
Table 2. ABTS •+ and DPPH• scavenging activity (IC50 [mg ml-1]) of methanol extracts of Asplenium ceterachsporophytes (S) and gametophytes (G).

\begin{tabular}{lrr}
\hline Samples & Radical scavenging activity $\mathrm{IC}_{50}{ }^{\mathrm{a}}$ \\
\hline & $\mathrm{DPPH}$ & ABTS \\
\hline & {$\left[\mathrm{mg} \mathrm{ml}^{-1}\right]$} & {$\left[\mathrm{mg} \mathrm{m}^{-1}\right]$} \\
\hline $\begin{array}{l}\text { A. ceterach } \\
\text { sporophyte (S) }\end{array}$ & $0.46 \pm 0.02 \mathrm{a}$ & $0.18 \pm 0.02 \mathrm{a}$ \\
$\begin{array}{l}\text { A. ceterach } \\
\text { gametophyte (G) }\end{array}$ & $30.47 \pm 3.26 \mathrm{~b}$ & $2.22 \pm 0.11 \mathrm{~b}$ \\
$\begin{array}{l}\text { Chlorogenic acid } \\
\text { Mangiferin }\end{array}$ & $8.64 \pm 0.38 \mathrm{c}$ & $5.44 \pm 0.12 \mathrm{~b}$ \\
Ascorbic acid & $7.27 \pm 0.54 \mathrm{c}$ & $3.20 \pm 0.03 \mathrm{a}$ \\
\hline
\end{tabular}

a Values are presented as the means of three independent measurements \pm SE. Within each assay, and for reference compounds independently, values with the same letter are not significantly different at the $\mathrm{P}<0.05$ level according to the LSD test.

\section{CONCLUSION}

Phytochemical analysis of rustyback fern provided for the first time data on phenolics' composition in both gametophytes and sporophytes and highlighted an interesting phenomenon. Not only that they represent different stages of the ferns ontogenetic cycle (vegetative and generative; diploid and haploid), but sporophytes and gametophytes are clearly diversified by their qualitative and quantitative phenolics' content. Sporophytes are characterized by the prevalence of phenolic acids (especially of chlorogenic acid), while xanthones (mangiferin glucoside) are the major group of phenolics in gametophytes. These phytochemical differences further influence their antioxidant properties. Results recommend Asplenium ceterach as a significant and alternative source of biologically active compounds, which can bring this species into the spotlight of pharmacological industry and medicine.

\section{ACKNOWLEDGMENTS}

Acknowledgment. This study was supported by the Serbian Ministry of Education, Science and Technological development (grant No. OI173024).

\section{REFERENCES}

Andrade, J., Dresch, R., dosS Passos, C., Kieling-Rubio, M., Moreno, P. R. and Henriques, A. (2014). Chemical analysis, antioxidant, antichemotactic and monoamine oxidase inhibition effects of some pteridophytes from Brazil, Pharmacognosy Magazine 10(37): 100.

Ansari, R. and Ekhlasi Kazaj, K. (2012). Adiantum capillusveneris. L: Phytochemical constituents, traditional uses and pharmacological properties: A review, J. Adv. Sci. Res 3: 1520.

Berk, S., Tepe, B., Arslan, S. and Sarikurkcu, C. (2011). Screening of the antioxidant, antimicrobial and DNA damage protection potentials of the aqueous extract of Asplenium ceterach DC., African Journal of Biotechnology 10(44): 8902-8908.

Bohm, B. A. (1968). Phenolic compounds in ferns-III: An examination of some ferns for caffeic acid derivatives, Phytochemistry 7(10): 1825-1830.
Brand-Williams, W., Cuvelier, M. and Berset, C. (1995). Use of a free radical method to evaluate antioxidant activity, LWT Food Science and Technology 28(1): 25-30.

De Britto, A. J., Gracelin, D. H. S. and Kumar, P. B. J. R. (2012) Phytochemical studies on five medicinal ferns collected from Southern Western Ghats, Tamilnadu, Asian Pacific Journal of Tropical Biomedicine 2(2): S536-S538.

Durdevic, L., Mitrovic, M., Pavlovic, P., Bojovic, S., Jaric, S., Oberan, L., Gajic, G. and Kostic, O. (2007). Total phenolics and phenolic acids content in leaves, rhizomes and rhizosphere soil under Ceterach officinarum D.C., Asplenium trichomanes L. and A. adiantum nigrum L. in the Gorge of Sićevo (Serbia), Ekologia Bratislava 26: 164-173.

Glass, A. and Bohm, B. (1969). A further survey of ferns for cinnamic and benzoic acids, Phytochemistry 8(3): 629-632.

Guarrera, P. and Lucia, L. (2007). Ethnobotanical remarks on Central and Southern Italy, Journal of Ethnobiology and Ethnomedicine 3(1): 23.

Guo, Q., Zhao, B., Shen, S., Hou, J., Hu, J. and Xin, W. (1999). ESR study on the structure-antioxidant activity relationship of tea catechins and their epimers, Biochimica et Biophysica Acta (BBA) - General Subjects 1427(1): 13-23.

Ho, R., Teai, T., Bianchini, J.-P., Lafont, R. and Raharivelomanana, P. (2011). Ferns: From Traditional Uses to Pharmaceutical Development, Chemical Identification of Active Principles, Working with Ferns, Springer, New York, NY, pp. 321-346. DOI: 10.1007/978-1-4419-7162-3_23.

Šiler, B., Živković, S., Banjanać, T., Cvetković, J., Nestorović Živković, J., Ćirić, A., Soković, M. and Mičić, D. (2014). Centauries as underestimated food additives: Antioxidant and antimicrobial potential, Food Chemistry 147: 367-376.

Imperato, F. (1983). A flavanone glycoside from the fronds of Ceterach officinarum, Phytochemistry 22(1): 312-313.

Kamiyama, M., Moon, J.-K., Jang, H. W. and Shibamoto, T. (2015). Role of Degradation Products of Chlorogenic Acid in the Antioxidant Activity of Roasted Coffee, Journal of Agricultural and Food Chemistry 63(7): 1996-2005.

Karadeniz, A., Cinbilgel, I., Gün, S. and Cetin, A. (2015). Antioxidant activity of some Turkish medicinal plants, Natural Product Research 29(24): 2308-2312.

Lai, H. Y., Lim, Y. Y. and Tan, S. P. (2009). Antioxidative, Tyrosinase Inhibiting and Antibacterial Activities of Leaf Extracts from Medicinal Ferns, Bioscience, Biotechnology, and Biochemistry 73(6): 1362-1366.

Mir, S., K Mishra, A., Reshi, Z. and Sharma, M. (2013). Preliminary phytochemical screening of some pteridophytes from district Shopian (J \& K), International Journal of Pharmacy and Pharmaceutical Sciences 5.

Ondo, J. P., Obame, L.-C., Andzi Barhe, T., Nsi Akoue, G., Nsi Emvo, E. and Lebibi, J. (2013). Phytochemical screening, total phenolic content and antiradical activity of Asplenium africanum (Aspleniaceae) and fruit of Megaphrinium macrostachyum (Marantaceae)., http://www.japsonline.com/counter.php?aid=1003 .

Pauline Vincent, C., Irudayaraj, V. and Johnson, M. (2012). Anti-bacterial efficacy of macroscopic, microscopic parts of sporophyte and in vitro cultured gametophyte of a fern Cyclosorus interruptus (Willd.) H. ito (Thelypteridaceae Pteridophyta), Journal of Chemical and Pharmaceutical Research 4: 1167-1172. 
Re, R., Pellegrini, N., Proteggente, A., Pannala, A., Yang, M. and Rice-Evans, C. (1999). Antioxidant activity applying an improved ABTS radical cation decolorization assay, Free Radical Biology and Medicine 26(9-10): 1231-1237.

Rice-Evans, C. A., Miller, N. J. and Paganga, G. (1996). Structure-antioxidant activity relationships of flavonoids and phenolic acids, Free Radical Biology and Medicine 20(7): 933-956.

Singleton, V. L. and Rossi, J. A. (1965). Colorimetry of Total Phenolics with Phosphomolybdic-Phosphotungstic Acid Reagents, American Journal of Enology and Viticulture 16(3): 144-158.

Soare, L. C. (2008). In Vitro Development of Gametophyte and Sporophyte in Several Fern Species, Notulae Botanicae Horti Agrobotanici Cluj-Napoca 36(1): 13-19.

Talukdar, A. D., Tarafdar, R. G., Choudhury, M. D., Nath, D. and Choudhury, S. (2011). A Review on Pteridophyte Antioxidants and their Potential Role in Discovery of New Drugs, Assam University Journal of Science and Technology 7(1): 151-155.

Vokou, D., Vareltzidou, S. and Katinakis, P. (1993). Effects of aromatic plants on potato storage: sprout suppression and antimicrobial activity, Agriculture, Ecosystems E Environment 47(3): 223-235.

Xu, J.-G., Hu, Q.-P. and Liu, Y. (2012). Antioxidant and DNAProtective Activities of Chlorogenic Acid Isomers, Journal of Agricultural and Food Chemistry 60(46): 11625-11630. 